\title{
India: Population Change and Its Consequences
}

\author{
DEEPAK LAL
}

In the 1980s I wrote two books-The Poverty of "Development Economics" (1983/ 2000) and The Hindu Equilibrium (1988/2005). ${ }^{1}$ The first questioned the intellectual consensus on dirigiste trade and development policies; the second, the view that India's age-old poverty was due to over-population. These repudiated views on which I was brought up in the early 1960s at Oxford. I know the first of these works of revisionism has had some effect in changing perceptions on the appropriateness of "outward-looking" policies for development. But I had not realized the once heretical view that the "population problem" is not a problem (except in the very short run, and only if appropriate policies are not in place) is also now very much the consensus view (see Kelley 2001). My late friend Julian Simon, who was universally reviled by mainstream economists for his view that a large population is a country's ultimate resource, is now seen to have been proved right by a burgeoning body of research. During the mid-1970s to mid-1980s I was also associated with the World Bank's research establishment. The sheaf of old memos in my files from those days demonstrates how entrenched was the old dirigiste consensus in an institution that is now seen as having been in the vanguard of the new revisionist consensus on population and development. ${ }^{2}$ So, returning in this essay to the issues discussed in the first edition of The Hindu Equilibrium, I feel rather like the old lady who went to see King Lear and found it full of quotations!

I will first review what is now known of the economic effects of population growth over the last century in India, including the emerging concerns that have been expressed by the environmental movement and why their attempts to legislate their "habits of the heart" pose real dangers for the welfare of the poor in India. ${ }^{3}$ I then examine the social and political consequences of this population growth. 


\section{Economic effects of population growth}

Many people find the Malthusian fear, that in a country with limited land and natural resources excessive human breeding will lead to the continuing immiserization of labor, intuitively obvious. At its crudest, this fear is based on the law of diminishing returns from increases in only one factor of production, and on the simple arithmetic of calculating per capita income as a ratio of gross national product to population. Thus if an infant is born to a cow, per capita income goes up, but if an infant is born to a human it goes down. But there is also an emotional response, expressed for instance by Paul Ehrlich, who in his famous book The Population Bomb writes: "I came to understand [the population explosion] emotionally one stinking hot night in Delhi.... The streets seemed alive with people. People eating, people washing, people sleeping. People visiting, arguing, and screaming. People thrusting their hands through the taxi window, begging. People defecating and urinating. People clinging to buses. People herding animals. People, people, people, people" (Ehrlich 1968: 15). Many Westernized Indians share this emotional response as well as the crude intellectualizing of the "population problem." So it is not surprising that Sanjay Gandhi believed that India's problems of poverty could be solved by coercive sterilization of the poor. The resulting civil resistance provoked by the mass sterilization camps and by the Emergency declared by his mother, Prime Minister Indira Gandhi, in the mid-1970s led to the virtual abandonment of family planning programs in India.

Yet, as economic historians and many eminent economists have known, Malthus had been overtaken by the "demographic transition," first in the West, then in East Asia, and by the time Sanjay Gandhi began his sterilization campaign, also in India. This can be seen from the relevant demographic data for the twentieth century in India, summarized in Table 1. As is well known from the new household economics (see Becker 1981, 1991) and the economic history of the industrial world, a decline in mortality, particularly infant mortality, due to better sanitation, vaccination, and other means of controlling infectious diseases, is followed with a lag by a decline in birth rates as families seeking the same completed family size adjust their childbearing habits to the new mortality regime. Furthermore, if economic progress raises the opportunity costs of the time spent in rearing children, parents will substitute quality for the quantity of children in their childbearing choices.

This path has been validated for India, which except for the brief period of the Emergency had an exhortative and informative rather than coercive family planning program. It is debatable whether India's family planning program had much effect in reducing fertility (see Mamdani 1972). India's demographic transition would have proceeded more rapidly if more 
TABLE 1 Demographic and economic change in India, census years, 1901-2001

\begin{tabular}{lllllllll}
\hline & $\begin{array}{l}\text { Annual } \\
\text { percentage } \\
\text { growth rate } \\
\text { of population }\end{array}$ & $\begin{array}{l}\text { Birth } \\
\text { rate }\end{array}$ & $\begin{array}{l}\text { Death } \\
\text { rate }\end{array}$ & $\begin{array}{l}\text { Growth } \\
\text { rate of } \\
\text { GDP }\end{array}$ & $\begin{array}{l}\text { lnfant } \\
\text { mortality } \\
\text { rate }\end{array}$ & \begin{tabular}{l} 
Life expectancy \\
\cline { 7 - 9 } Female
\end{tabular} & $\begin{array}{l}\text { Male } \\
\text { per capita } \\
\text { GDP }\end{array}$ \\
\hline 1901 & 0.30 & 49.2 & 42.6 & & 210 & & & \\
1911 & 0.56 & 48.1 & 47.2 & 2.1 & 204 & 23.3 & 22.6 & 1.5 \\
1921 & -0.03 & 46.2 & 36.3 & -0.8 & 219 & 20.9 & 19.4 & -0.9 \\
1931 & 1.06 & 45.2 & 31.2 & 2.3 & 174 & 26.6 & 26.9 & 1.3 \\
1941 & 1.34 & 39.9 & 27.4 & 0.8 & 161 & 31.4 & 32.1 & -0.6 \\
1951 & 1.26 & 40.9 & 22.8 & -0.5 & 146 & 31.7 & 32.4 & -1.7 \\
1961 & 1.98 & 40.0 & 17.6 & 3.7 & 129 & 40.6 & 41.9 & 1.8 \\
1971 & 2.20 & 37.8 & 15.4 & 3.3 & 110 & 44.7 & 46.4 & 1.0 \\
1981 & 2.22 & 34.0 & 13.0 & 3.5 & 92 & 54.7 & 54.1 & 1.2 \\
1991 & 2.14 & 30.0 & 10.0 & 5.4 & 75 & 60.9 & 59.7 & 3.1 \\
2001 & 1.93 & 26.0 & 9.0 & 6.2 & 70 & 61.8 & 60.4 & 4.3 \\
\hline
\end{tabular}

SOURCE: Lal (2005).

intensive public health measures had been taken to reduce infant mortality and if the country's economic growth rate had been increased by an earlier abandonment of the dirigiste Nehruvian model of development.

The most sophisticated argument for public action to limit fertility was based on the purported "market failure" attributable to technological (not pecuniary) externalities, which caused a discrepancy between the private and public costs of childrearing. ${ }^{4}$ The empirical study by Lee and Miller (1990) found positive or no Pareto-relevant economic external effects from childbearing, and the negative externalities they did find for India (and Saudi Arabia) were entirely due to the presumed dilution by a larger population of the average claim on the country's mineral wealth, mainly coal. But this is a factor of little relevance in a globalized world, where a country's wealth no longer depends directly on its location-specific mineral resources. Moreover, as Lee and Miller note, "if we take the plausible view that Indian coal reserves have low value, then India would...[have] net externalities close to zero" (p. 290). Hence their conclusion in favor of a laissez-faire population policy that does not "go beyond assisting well-informed parents to attain the family size goals they seek" (p. 296).

\section{Demographic trends}

Figure 1 charts the crude birth and death rates for India during the past century from the censuses, ${ }^{5}$ while Figure 2 charts the growth rates of population, per capita GDP, and GDP. ${ }^{6}$ The decline in the death rate, as demographic transition theory predicts, has been faster than the fall in the birth rate, so that the population growth rate continued to rise until 1981. Since 
FIGURE 1 India: Birth and death rates 1901-2001

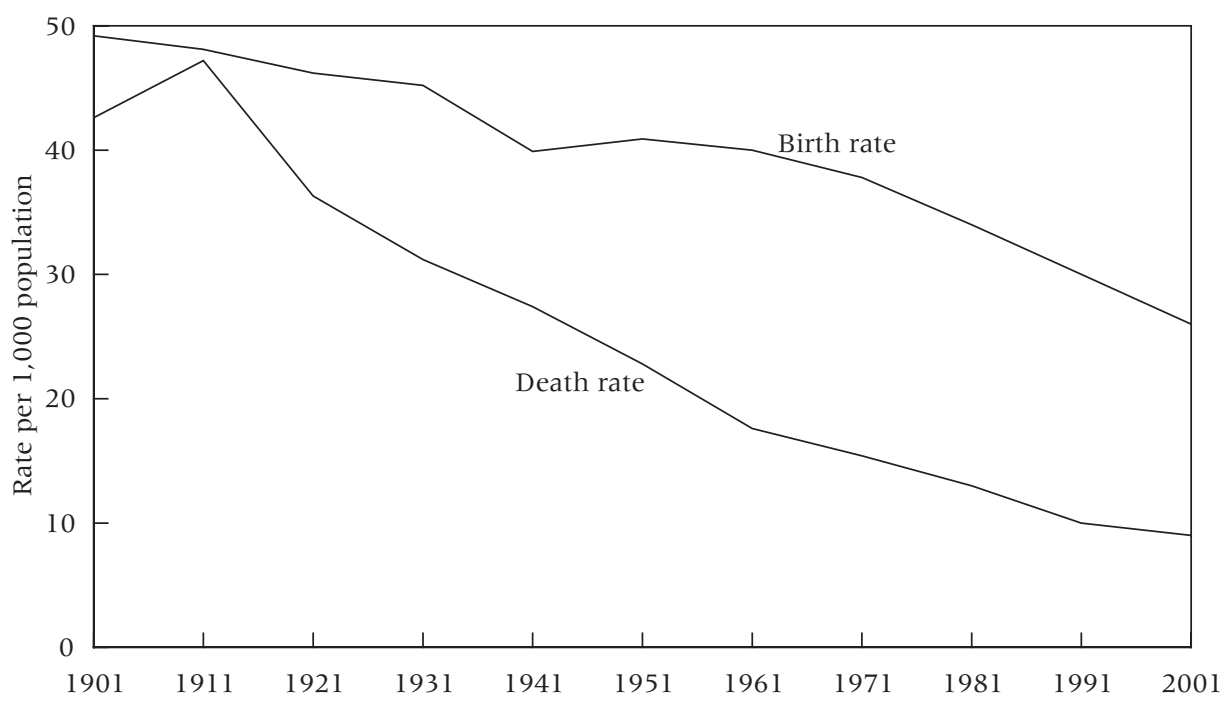

then the birth rate has been declining faster than the death rate. Figure 3 charts the birth rate and the infant mortality rate. ${ }^{7}$

There has been a rise in the mean age at marriage and a decline in the age-specific marital fertility rate, the latter attributable to the spread of contraceptive practices. But, as Visaria (1987) noted, "it is futile to discuss

FIGURE 2 Growth rates of population, GDP, per capita GDP, India 1901-2001

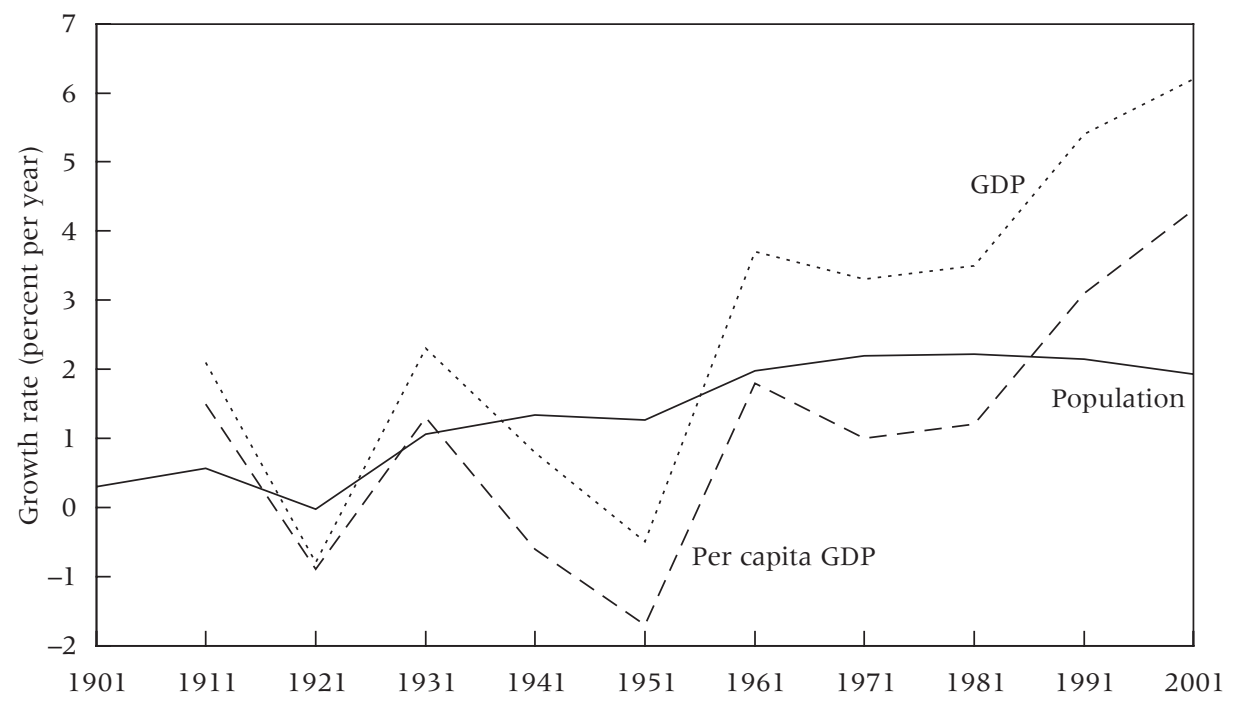


FIGURE 3 Birth rates and infant mortality rates, India 1901-2001



whether the increase in the level of contraception should be attributed wholly or only in part to the official program to promote family planning" (p. 140). The sex ratio of the population rose from 1029 males per 1000 females in 1901 to 1079 in 1991 and then fell slightly to 1071 in $2001 .^{8}$

The masculinity of the Indian population has spawned a large literature attempting to explain the male sex bias, particularly in the northern as compared with the southern states (see Mayer 1999 for a succinct survey). But as Mayer rightly argues, given the historical sex bias in favor of males in India, particularly in the north, the rise in the sex ratio still needs to be explained. If it is to be explained as purely due to the anti-female bias of Indians, this bias would have to be increasing to yield the trends in increasing masculinity over the twentieth century. But, as can be seen from Figure 4, which charts the sex ratios and the life expectancy at birth for males and females, female life expectancy has been rising along with the rising sex ratio, so there could not have been a rising sex bias against females-what Mayer labels the "mortality paradox." This question is resolved by observing from Figure 4 that life expectancy for females did not catch up with and surpass that for males until 1981. The lag in the decline of female mortality as compared with that for males is sufficient to explain the rising sex ratio. For "if successive cohorts of children born in the intervals between decennial censuses experience higher rates of survival than those that have preceded them, then those cohorts will be correspondingly larger. If the boys in each of those new cohorts experience slightly greater improvement than the girls, then we might well find that while all children gain in survival, 
FIGURE 4 Sex ratio (M/F) and life expectancy at birth for males and females, India 1901-2001

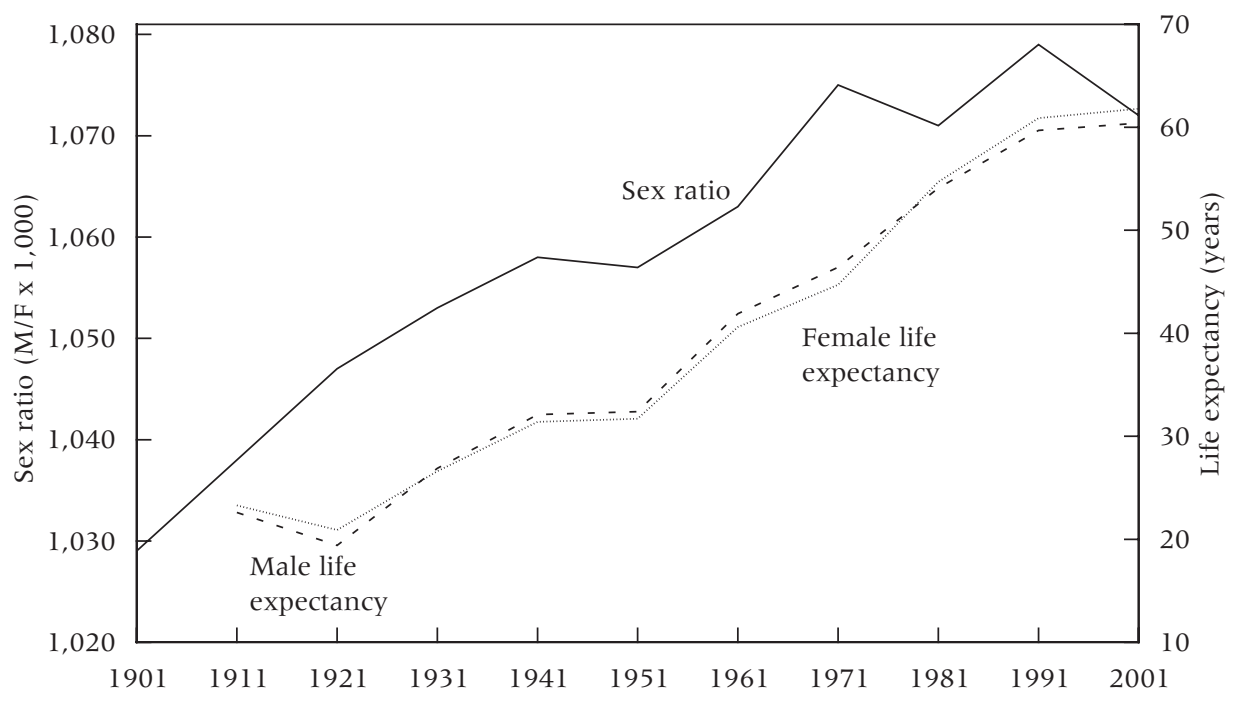

during the period of population transition the number of males would become larger than the number of females (Mayer 1999: 334-335).

China, too, has the growing problem of a highly distorted sex ratio. It has been suggested (Oster 2005; Barro 2005) that the problem of the missing women (Sen 1990) in both India and China is caused by the prevalence of hepatitis B in women, which leads to their giving birth to a higher proportion of male children than the norm. But, in a recent examination of this biological thesis, Das Gupta (2005) convincingly shows, by examining the sex ratios for different birth orders, that for both India and China the sex ratio is "closely related to the sex composition of the children already born in the family" (p. 533). Hence biological factors cannot provide the dominant explanation, and the main causes for the overall sex bias appear to be sex-selective abortion and neglect of female infants, based on the cultural preference for males in certain regions in both countries.

These aggregate trends, of course, conceal very large regional variations in a vast country with a great variety of ecological conditions, which as we know (see Lal 1998; Goody 1990, 1996) influence family patterns and "heirship strategies" in premodern agrarian societies and, thence, demographic trends. Mari Bhat's (1998) mapping of fertility regimes in the districts of India from the census data for 1981 and 1991 shows the northsouth divide and the decline in fertility moving inward from the coast. His multivariate analysis of the data shows that the case for patriarchy and female autonomy as causes of regional variations in fertility has been overstated, and that differences in social structure (rather than structural fac- 
tors) and ideational factors (mainly due to differences in exposure to the mass media) are the major variables explaining the differences in fertility across districts. But, as Dyson (2001) notes there is evidence from the 2001 census that while in most states the rise in the male sex ratio is fairly modest, in Punjab, Haryana, Maharashtra, and Gujarat there has been a marked rise in the male child sex ratio since 1991, which is due to sex-selective abortions (Das Gupta and Bhat 1999). Explaining this in terms of the new household economics should be a fruitful topic for future research.

Even anthropologists (see Goody 1990) argue that divergences in the domestic domain are conditioned by differences in ecological regimes, forms of social stratification, differing needs for insurance (see Rosenzweig 1988), and heirship strategies. Two examples will have to suffice. Numerous observers have commented favorably on the balanced sex ratio in the state of Kerala, along with its positive social indicators despite low economic growth. It is not often noted, however, that polygyny, which is uncommon among human populations (see Kuper 1994), arose among the Nairs of Kerala. Particular historical circumstances led Nair men to specialize as mercenary soldiers, who were absent for long periods, which led to the female-based family arrangements, which in turn made this way of life possible. When, after annexing Malabar, the British in 1792 suppressed the military system that had underwritten this domestic system, polyandry also died out. But the enhanced status of women and its social and economic correlates cast a long shadow on the social performance of Kerala. In the context of the relationship of population growth and various social indicators to be discussed below, it should be noted that, despite these better social indicators, the level of malnutrition in Kerala is among the highest in India (see Kumar 1993). This is probably because of "the weaknesses in real economic performance [which] have arguably played a crucial role in restraining the capacity of the economy to stimulate employment conditions, increase incomes and nutritional levels, and thereby raise long-term living standards" (ibid.: 337). This underlines the importance of economic growth in the sustainable alleviation of poverty (see Lal and Myint 1996).

The second example is the study by Monica Das Gupta (1998) of fertility decline in 11 villages of Ludhiana district that were originally part of the famous Khanna study (Wyon and Gordon 1971). As she notes, fertility decline started in this area when the "society was overwhelmingly agrarian, illiterate, had infant mortality well above 150 per thousand livebirths, and was without modern contraceptive technology" (p. 91). She finds that historically, as in Europe, joint families tried to keep a balance between population and available resources through regulating marriage and through permanent celibacy to avoid subdivision of land, given the system of partible inheritance. These traditional means of dealing with fluctuations in 
population were inadequate when sustained mortality decline began in the 1920s. This then led to a concerted effort at fertility reduction, so that "By the time Mamdani visited this area and concluded that for these people reducing fertility would mean 'courting economic disaster,' the total fertility rate had already fallen by nearly 40 per cent, and all the socioeconomic groups in these villages were engaged in rapid fertility decline" (p. 92).

The major conclusion we can derive from these noneconomic perspectives is that, at the micro level, there is likely to be a complex pattern of fertility decline as well as changes in the sex ratio. But households are still responding to the underlying forces determining the macro picture-the decline in infant mortality rates, followed by a decline in birth rates-and even at the micro level the material factors-the relationship of population to available resources, the nature of localized risks, and heirship strategiesare all best studied as part of the new household economics.

It is instructive to compare India's more laissez-faire approach to population control with the coercive policies adopted by China through its draconian one-child policy. These coercive policies undoubtedly accelerated China's demographic transition, but they have bred serious problems for the future. The most important is the premature aging of its population, which is projected to begin in 2010, with the ratio of the working-age population to retirees falling from 6 today to 2 in 2040 (UN 2002), when even with its current spectacular economic growth rate China will confront the problems of caring for the old currently facing most developed countries but with possibly a lower per capita income. Equally serious is the social stress likely to be caused with the ending of the Maoist "iron rice bowl" and the privatization of health, education, and housing, along with the emergence of the "4-2-1" phenomenon: four grandparents and two only-child parents being supported by one child. Finally, and perhaps most important is the welfare loss the Chinese have suffered as a result of having their preferences for children (and the joy they bring) being overruled by a coercive state.

By contrast India, with its more natural demographic transition, will not see an aging of its population until after mid-century. This, of course, implies that India's population is expected to stabilize at a much higher level (1.6 billion) than China's ( 1.4 billion). But with its traditional family systems still secure (see Lal 2006), India should be able to cope better than China with the eventual aging of its population, particularly if it completes its economic reforms and continues growing at its potential rate of growth of about 8 percent per annum for the next few decades.

\section{Employment, poverty, and population growth}

This leads us to the effects of population growth on employment and wages and thus on poverty. The main fear underlying the population problem was 
that all these indicators of socioeconomic performance would be worsened by rapid population growth. As I noted in The Hindu Equilibrium (1989, vol. 2: 10-11), these fears seemed to ignore the most simple outcomes of an open economy. As the well-known Rybczynski and Stolper-Samuelson theorems of trade theory show, in an open economy the effect on the real wage of a population expansion depends upon what happens to the relative world price of the labor-intensive goods whose production will expand with the expansion of the labor supply. If there is no change in this relative price, there will be no change in the real wage. Also, of course, without any barriers to employment in such a model, there is no need for any of the additional labor to be unemployed. Thus there is no necessity of any increase in unemployment or poverty caused by declining wages following a population increase in an efficient open economy. ${ }^{9}$

These predictions have been borne out for India (Lal 1989, vol. 2). Despite the large increase in population, the National Sample Survey (NSS) data indicate that "rates of unemployment in India have not only (a) been low between 1972-73 and 1987-88, but also (b) have declined between 1983 and 1987-88, and that (c) this decline does not seem to have been at the cost of an increase in visible unemployment" (Visaria and Minhas 1991/ 1993: 149). Nor has there been any decline in labor force participation rates, which according to the NSS have been stable since the 1960s at "around 41-42 percent" (ibid.: 139).

This is so despite the slow growth of employment in the formal organized sector at the rate of 1.6 percent per annum between 1979 and 1989 (ibid.: 142). During the era of partial reform, organized-sector employment rose from 26.4 million in 1990 to 28.1 million in 1999, that is, at the rate of only 0.65 percent a year. This reflects the capital-intensive bias of Indian industrialization, which goes back to the implicit tax on labor that was instituted in the late nineteenth century by the various labor laws introduced by the British Raj and maintained to this day by the government of India (see Lal 1988, vol. 1: 208-209, 260-264; also see Visaria and Minhas 1991/ 1993: 152).

Much of the increase in employment has been in the service and construction sectors. Thus, from NSS data it appears that, between 1972 and 1988, while agriculture's share in the industrial distribution of increments to the male workforce declined from 40 percent to 12 percent and while that of mining and manufacturing was stable at around 19-20 percent, construction's share rose from 3.4 to 19.6 percent and that of trade and restaurants from 18 to 23 percent, and of other services from 9 to 14 percent (Visaria and Minhas 1991/1993: Table A3). Banking and insurance grew at the rate of 13.1 percent per annum between 1980 and 2000, while communications (which includes the information technology sector) has grown at the rate of 16.6 percent per annum since the reforms of 1991 . There has 
been a large increase in public administration and defense, whose relative share in GDP has risen from 3.1 percent in 1950-51 to 7.8 percent in 19992000 (Sivasubramonian 2000: 601, 604).

Nor, as had been feared, has the eight-fold increase in high school and college graduates from 1961 to the late 1980s led to a worsening of unemployment among the educated (see Blaug, Layard, and Woodhall 1969). The data from the three NSS surveys of 1977-78, 1983, and 1987-88 "show a clear decline in the unemployment rates for the matriculates and the higher educated" (Visaria and Minhas 1991/1993: 147). Much of the increase in employment of the educated has been in self-employment. The rise in the rate of unemployment as measured by the employment exchange registrations is not a true measure of educated unemployment, as there is no requirement for those on the register to be unemployed. As outlined in Lal (1989, vol. 2), the numbers on these registers reflect the excess demand for public sector jobs, which usually pay a higher wage with security of tenure than equivalent private sector jobs, and to get these jobs the applicant has to be on the register. So, as I showed in Lal (1988a, 1989), the numbers on the unemployment register can be explained in terms of a variant of the well-known Harris-Todaro migration model, as depending upon the changing public-private sector wage differential.

The most enduring myth about the relationship of population growth, wages, and poverty was the belief in the existence of vast pools of surplus labor in India. Following on from the models of Lewis (1954) and Fei and Ranis (1964), it was believed that, because of overpopulation, there was a perfectly elastic supply of rural labor available at a given institutional wage. This implied that until the surplus was absorbed through increases in the demand for labor greater than the increments in supply, there would be no rise in wages (whether rural or industrial) for the mass of Indian workers, and hence no alleviation of India's age-old poverty. In The Hindu Equilibrium I argued against this Malthusian view and showed how the alternative Boserupian perspective better described the changing fortunes of the rural countryside.

As is well known, Boserup (1965) argued that population pressure both induces and facilitates the adoption of more intensive forms of agriculture. She identifies the differing input-per-hectare requirements of different agrarian systems by the frequency with which a particular piece of land is cropped. Thus settled agriculture is more labor- and capital-intensive than nomadic pastoralism, which in turn is more intensive in these inputs than hunting and gathering or the slash and burn agriculture practiced until recently in parts of Africa and the tribal regions of India. Contrary to Malthusian presumptions, she argues that population growth leads to the adoption of more advanced techniques that raise yields per hectare. Because these new techniques require increased labor effort, they will not be adopted until rising 
population reduces the per capita food output that can be produced with existing techniques and forces a change. ${ }^{10}$

Boserup's theory is of considerable interest in explaining India's longrun agricultural growth performance. In The Hindu Equilibrium I provided some tentative and imperfect evidence that the population of the subcontinent in times of peace and stability remained relatively constant between 100 and 140 million from about 320 BC until the late eighteenth century. There was a mild expansion of about 0.45 percent per annum in the nineteenth century and the early part of the twentieth. From the 1920s, as we have seen, population has increased steadily because of the dramatic reductions in mortality. Because of the time it takes humans to reach adulthood, however, the population bulge did not affect the rural labor supply until the 1950s. Thus the Malthusian fear of the immiserization of labor could be expected to be most potent in the period after Independence.

Indian agriculture grew relatively slowly until 1946, at about 0.94 percent per annum between 1878 and 1900, and at 0.62 percent per annum between 1900 and 1946. But since Independence from 1950-51 to 198384 growth accelerated to 2.18 percent. This improved agricultural performance was responsible for the modest growth in per capita income of about 1.39 percent per annum from 1950-51 until the early 1980s. From 198081 until 1999-2000, agriculture grew at the rate of 3.2 percent per annum, which exceeds the population growth rate of 2 percent per annum over the period, while per capita income has grown at the rate of 3.1 percent per annum between 1980 and 1991 and at the rate of 4.3 percent since the reforms of 1991. Thus, looked at in the broad sweep of history, population growth and agricultural growth have gone hand in hand in India. There is evidence that this was due to the Boserupian process.

First, until recently Indian agriculture was faced with a shortage of labor. Thus, for instance, even in 1965-70 total agricultural area per inhabitant in India was 0.33 hectares compared with 0.06 for Japan. Until about 1921, the modest expansion of population was accommodated by extending the land frontier, with relatively unchanged technology and cropping patterns. Thereafter, more intensive methods of cultivation were called for. Comparing the period 1901 to $1940-41$ with 1950-51 to 1970-71 (see Table 2), we see a rise in the output/labor ratio. This was achieved by a more rapid extension of both the net sown area and the double-cropped area, so that the total cropped area increased between 1950 and 1971 in rough proportion to the rural work force. More remarkable was the change in the rate of capital formation in agriculture in the two periods, with the capital/labor ratio being stagnant in the first period, and rising by over 30 percent between 1950 and 1970. Part of this increased capital formation was of the land-saving variety (mainly in the form of irrigation, which permits multiple cropping). Clearly in this second period, as compared with the first, capital was being used to 
TABLE 2 Agricultural ratios and elasticities

\begin{tabular}{lrrr}
\hline & $\mathbf{1 9 0 1 - 4 1}$ & $\mathbf{1 9 5 0 - 7 0}$ & $\mathbf{1 9 7 0 - 2 0 0 0}$ \\
\hline Percent change & 16.8 & 35.3 & 28.2 \\
Output/labor & na & 3.8 & 4.9 \\
Output/capital & 0 & 31.1 & 21.6 \\
Capital/labor & & & \\
Capital/land & na & 39.2 & 102.3 \\
$\quad$ Net sown area & na & 30.7 & 82.3 \\
$\quad$ Total sown area & -8.7 & -6.1 & -39.8 \\
Land/labor & -6.7 & 0.8 & -33.6 \\
$\quad$ Net sown area & & & 1.7 \\
$\quad$ Total sown area & 2.5 & 2.7 & \\
Elasticities & & & 0.02 \\
Output/labor & 0.22 & 0.71 & 0.18 \\
Land/labor & 0.36 & 1.03 & 8.2 \\
$\quad$ Net sown area & & & 1.53 \\
$\quad$ Total sown area & 11.29 & 3.85 & \\
Output/land & 7.02 & 2.71 & \\
$\quad$ Net sown area & na & 2.54 & \\
$\quad$ Total sown area & & & \\
Capital/labor & & & \\
\hline
\end{tabular}

SOURCE: Lal $(1988,2005$ : Table 7,4) and derived from official statistics.

substitute for land, which was becoming scarce, as is evident from the steady decline in the land/labor ratio over the 70 -year period.

Various elasticity estimates derived in Table 2 bear out the role of population growth in driving these changes. The elasticity or responsiveness of output with respect to labor supply remained relatively constant over the two periods-a cornerstone of Boserup's hypothesis. But the responses to the differing growth rates of labor supply were markedly different in the two periods. The elasticity of land and capital with respect to labor increased greatly from the pre-Independence period when labor supply growth was low, to the post-Independence period when it was more rapid. The elasticity of double-cropped land with respect to labor supply rose to unity, through the increase both in new land and in multiple cropping. But the most important factor keeping the elasticity of output with respect to labor constant has been the marked rise in the capital/labor supply elasticity. Because much of this capital formation is labor intensive, we can assume, following Boserup, that it is more likely the increased labor supply induced this increased capital formation than the other way around.

Since 1970, there has been virtually no increase in the net sown area, but a 12 percent increase in the gross sown area between 1970 and 1990 . This increase is largely due to the increase in the percentage of the net sown 
area that is irrigated, which has risen by 115 percent between 1970 and 1990 (see Lal 2005: Ch. 11.4). Output per laborer was virtually stagnant between 1970 and 1980, but rose by 18.3 percent from 1980 to 1990 and 18.4 percent between 1990 and 2000. This reflects the spread of the Green Revolution, with the fraction of the total cropped area under high-yielding varieties rising from 15.1 percent in 1970-71 to 66.6 percent in 1993-94.

Two other pieces of evidence support Boserup's thesis. First is the near constancy of per capita net domestic product in agriculture from 1950-51 to 1984-85 (see Dandekar 1988). But it has risen by 21 percent between the mid-1980s and 2001. So, I would conjecture that after the mid-1980s the Boserupian process has ended, with agricultural growth becoming dependent on shifts in the production function associated with technical change rather than on the increasing labor intensity of production induced by population expansion.

Second, what I have called the Ishikawa curve for the Indian states for 1970-71 also supports the Boserup hypothesis for Indian agriculture. Ishikawa (1967) argues that in the traditional subsistence cultivation of rice, the relationship between land productivity and per farm holding of cultivated land is a rectangular hyperbola, so that, roughly speaking, increases in total output keep pace with rural labor supply (which is the force reducing farm size). Figure 5 shows the Ishikawa curve for the Indian states in 1970-71. Because Punjab and Haryana had already begun their Green Revolutions, moving them out of the traditional subsistence agricultural process, they were excluded from the statistical estimation. As Figure 5 shows, apart from these two states, the others were taking part in the Boserup process-

FIGURE 5 Ishikawa curve for 1970-71

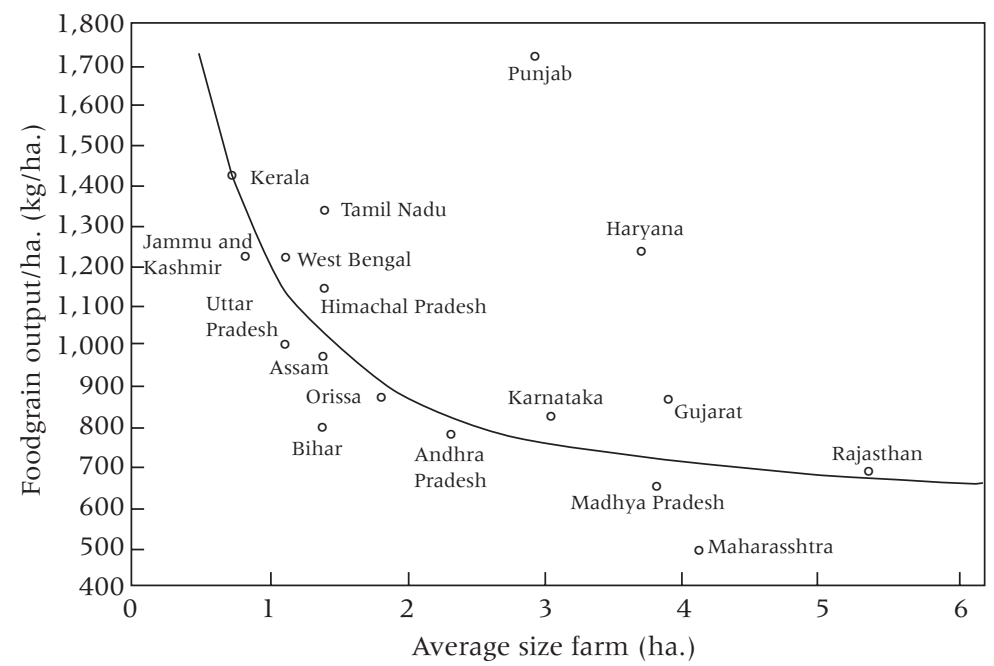


crawling up the Ishikawa curve with population expansion. Since then, many other states have moved away from the Ishikawa curve thanks to the Green Revolution (see Lal 2005: Figure 11.4(b)).

If the Boserupian process applies to India, one of the basic assumptions underlying the surplus labor view would be invalid. Surplus labor in India has been estimated as the amount of surplus labor time that is available from some given norm of working hours per day (see Mehra 1966). But in an economy undergoing a Boserupian transformation, the surplus of labor time would be very high in the least labor-intensive form of agriculture because the labor input required to obtain the necessary food output would be very low. This surplus of labor time would then decrease as we looked at more and more intensive agricultural systems with their increasing labor input required to keep per capita food output constant. This transformation would not tell us anything about the supply price of rural labor in these systems. Once we take account of the wage at which people are willing to work, taking account of the leisure-versus-income choice facing rural labor, then, even in overpopulated countries (as Sen 1966 showed), surplus labor in the sense of a constant (perfectly elastic) supply of labor at a given wage would imply that leisure was an inferior good.

That this is not so is borne out by various studies which have estimated wage elasticities for rural labor in India (see Lal 1989, vol. 2; Bardhan 1979, 1984; Rosenzweig 1978, 1980; Evenson and Binswanger 1984). They provide powerful evidence against the hypothesis of a horizontal supply curve of rural labor supply. They find that the wage elasticities of both rural labor demand and supply are low. Therefore, far from increases in demand not increasing rural wages, one can expect, ceteris paribus, a substantial increase.

In terms of the Boserupian process, over a long historical time scale we would expect that with population expansion the supply curve for labor would shift rightward with an accompanying rightward shift in the demand curve to maintain a relatively constant per capita level of living (implicit rural wage). Around this long-term trend, however, there would be large short-term shifts (in both directions) in the labor demand curve due to variations in the climate, which, given the low wage elasticities, would lead to large short-term movements in real agricultural wages around a nearly constant trend. This is what the historical record shows to have been true of rural wages, until the recent Green Revolution led to a massive increase in the demand for labor and thence a marked rise in rural real wages (see Lal 1989, vol. 2).

Because the surplus labor hypothesis is invalid, so is its corollary that mass poverty would not be alleviated until the rural labor surplus is removed. This can be seen from Table 3, which gives data on the poverty ratios for rural and urban India from the NSS and the National Council of Applied Economic Research (NCAER) household survey data. Of these, for 
TABLE 3 Poverty headcount ratios: India (percent)

\begin{tabular}{lrrrrr}
\hline & \multicolumn{2}{l}{$\begin{array}{l}\text { Planning Commission } \\
\text { (NSS) }\end{array}$} & & \multicolumn{2}{l}{ NCAER } \\
\cline { 2 - 3 } & Rural & Urban & & Rural & Urban \\
\hline $1970-71$ & 57.33 & 45.89 & & \\
1983 & 45.6 & 40.79 & & \\
$1987-88$ & 39.09 & 38.2 & & 39.09 & 38.02 \\
$1993-94$ & 37.27 & 32.36 & & 30.86 & 24.37 \\
$1997-98$ & 38.5 & 34 & & 17.98 & 12.63 \\
\hline
\end{tabular}

SOURCE: Tendulkar (1998); Lal, Mohan, and Natarajan (2001).

the reasons explained in Lal, Mohan, and Natarajan (2001), the NCAER series is the more reliable. It is by now a well-established stylized fact that the only cure for mass structural poverty is rapid income growth, with poverty ratios falling as soon as countries' per capita incomes are growing above about 2.5 percent per annum (Lal and Myint 1996). Not until the 1980s, when Indian per capita income growth rose above what had been termed the "Hindu rate of growth" of about 1.5 percent, did poverty ratios start falling, and the fall accelerated with the boost to the GDP growth rate given by the partial liberalization of the economy in the wake of the economic reforms in 1991.

Table 4 summarizes Sivasubramonian's (2000) estimates of the sources of growth for the pre-Independence period (1900-01 to 1946-47) and for the period 1950-51 to 1997-98. There is no evidence that the increase in the population growth rate has adversely affected GDP growth. In fact, in the period of high population growth following Independence, total factor

TABLE 4 Sources of growth of real GDP: India 1901-97/98

\begin{tabular}{|c|c|c|c|c|c|c|}
\hline \multirow[b]{2}{*}{ Rates of growth } & \multicolumn{3}{|c|}{$\begin{array}{l}\text { Undivided India } \\
1900-01 \text { to } 1946-47\end{array}$} & \multicolumn{3}{|c|}{$\begin{array}{l}\text { India } \\
1950-51 \text { to } 1997-98\end{array}$} \\
\hline & Agriculture & $\begin{array}{l}\text { Non- } \\
\text { agriculture }\end{array}$ & Total & Agriculture & $\begin{array}{l}\text { Non- } \\
\text { agriculture }\end{array}$ & Total \\
\hline GDP & 0.44 & 1.69 & 0.92 & 2.6 & 5.1 & 4 \\
\hline Persons employed & 0.4 & 0.42 & 0.41 & 1.5 & 2.1 & 1.7 \\
\hline $\begin{array}{l}\text { Capital stock } \\
\text { including land }\end{array}$ & 0.45 & 3.02 & 1.13 & 2.5 & 4.5 & 4 \\
\hline Combined factor inputs & 0.41 & 1.12 & 0.56 & 1.69 & 2.74 & 2.22 \\
\hline $\begin{array}{l}\text { Increase in output per } \\
\text { unit of input }\end{array}$ & 0.03 & 0.57 & 0.36 & 0.91 & 2.36 & 1.78 \\
\hline
\end{tabular}

SOURCE: Sivasubramonian (2000: Tables 7.21 and 9.34.). 
productivity growth accelerated in both agriculture and nonagriculture. Thus population growth, far from damaging, has probably helped economic performance, and fears concerning the effects on wages, employment, and poverty have proved to be misplaced. It is owing to India's failure-until the 1990s - to accelerate its growth rate, because of the inward-looking dirigiste economic policies it adopted in the post-Independence Nehruvian era, that performance on these fronts has not been even better. ${ }^{11}$

\section{Demographic transition, dependency, savings, and growth}

One of the inimical effects of population growth was supposed to manifest itself through rising dependency ratios, which depressed savings and thus damaged economic growth. This conventional channel has now been turned on its head as a result of the work of Jeffrey Williamson and his colleagues (Williamson 2001). They argue that the effect of demographic change on economic performance depends on what happens to the age distribution. Thus, per capita income growth is thwarted in the early stages of the demographic transition as the dependency ratio rises: smaller shares of the population of working age mean fewer savers and workers. But over time, as the transition proceeds, the youth dependency ratio falls as the share of working-age adults rises, leading to more workers and savers and hence higher per capita income growth. This higher share of adult workers becomes an economic gift-assuming it is efficiently used. The gift fades with the end of the transition and a rise in the share of the elderly.

Figure 6 charts the population growth rate and the share of workers in the population for the past century. The share of workers declined until 1971 but, as population growth slowed, has been rising since then. Figure 7 charts the savings rate (which is only available for the period since 1951) and the share of workers in the population. As can be seen there is no relationship at present of the sort postulated by Williamson.

In fact, Williamson's view is an adaptation of the well-known life cycle/ permanent income (LC-PI) theories of savings. These theories posit a relationship between savings and growth through life-cycle "hump savings" (Harrod 1948). Savings are independent of the level of permanent income and also of the distribution of income (Modigliani 1970). But, as Summers and Carroll (1989) note, the positive empirical relationship between savings and growth, if it is due to the life cycle, should show up in differences in the age-consumption profiles of countries with differing growth rates. This is not so for comparisons of Japan, Canada, and the United States. Deaton (1990) also finds that it is not so for comparisons of the Ivory Coast, Hong Kong, rural Indonesia, urban Korea, and Thailand.

Furthermore, for individual developing countries, as Deaton (1990) notes, the key prediction of the life-cycle hypothesis of a unitary elasticity of 
FIGURE 6 Population growth rate and share of workers, India 1901-2001

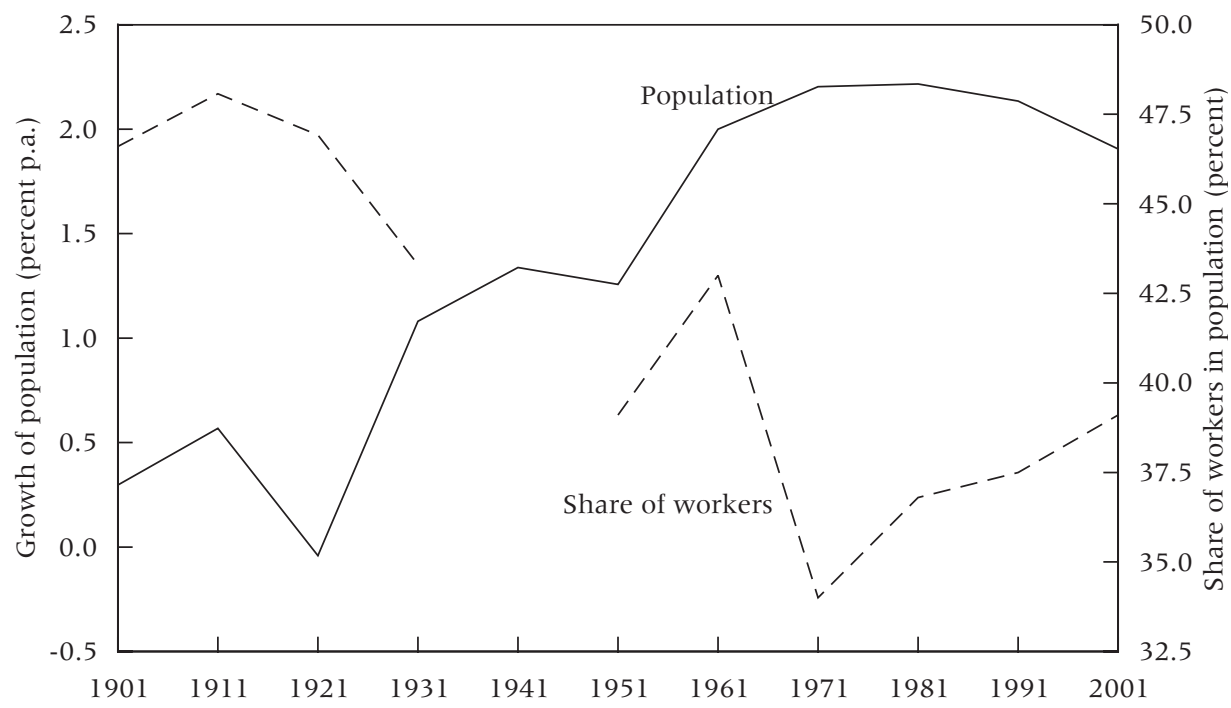

consumption with respect to permanent income has been uniformly rejected. For India, Bhalla $(1979,1980)$ finds it is less than unity-so savings are not independent of the level of income. This, of course, is the assumption underlying the Keyensian consumption function, where average savings rates increase with income. Moreover, in Kaldor's version (Kaldor 1955-56), the distribution of income between capitalists and workers with differing propensities to save is an important determinant of the overall savings rate.

FIGURE 7 Savings rate and share of workers in population, India 1901-2001

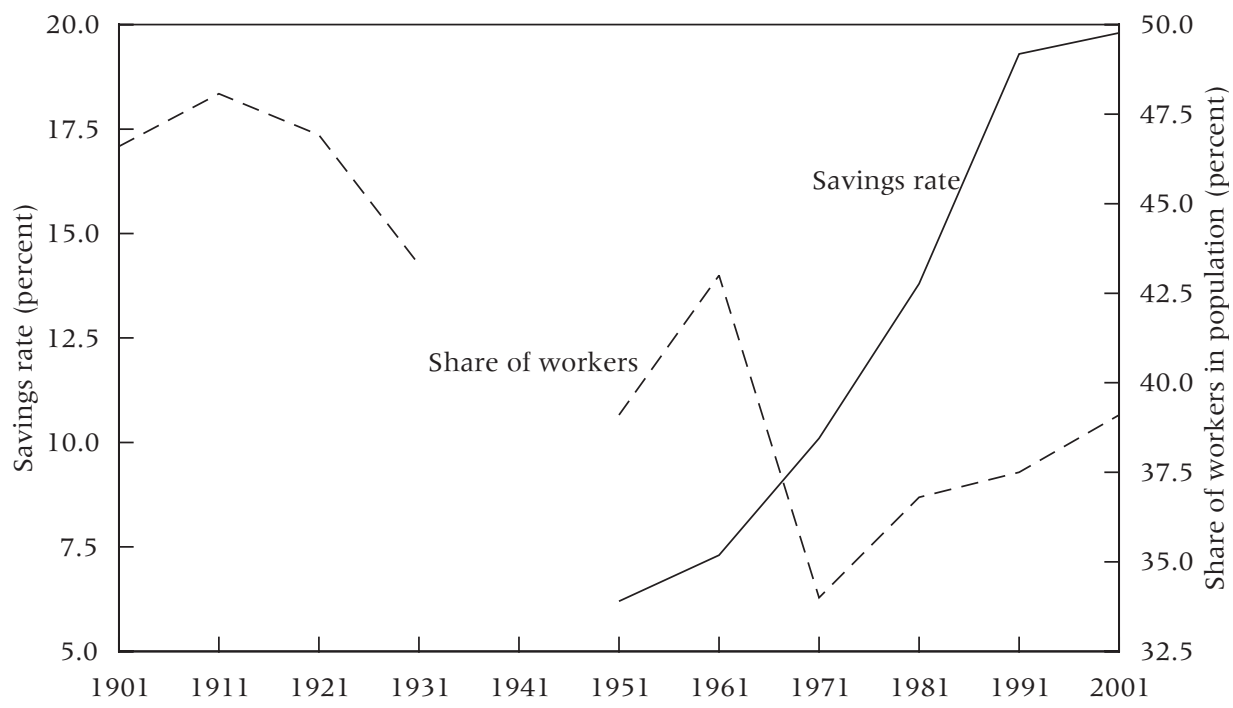


Bhalla (1980) provides the most robust study of savings behavior in rural India based on NCAER's three-year longitudinal sample survey data for 1968-70. This savings function behaves in Keynesian fashion during the middle-income range and then at higher income levels asymptotically approaches a savings rate that is constant and independent of permanent income in line with the life-cycle hypothesis. This savings function can be rationalized in terms of a model that combines the hump savings underlying the life-cycle model with a model of "precautionary savings" developed by Deaton (1990) in which, in poor agrarian economies subject to climatic risk, savings are motivated by the desire to smooth consumption between good and bad years.

This discussion provides a link between the distribution of households by different income levels and aggregate savings. With savings rising with assets and thus with permanent income, the effects of growth on savings will be mediated through the effects on the income-asset levels of different households. One robust finding of the Lal-Myint (1996) study is that growth trickles down-and as we have seen, this is also the case for India-with the poverty ratio declining faster the more rapid per capita income growth. Because the savings propensity increases with the household's income level, growth shifts households of the low (or zero and negative) income-savings classes into higher (and positive) income-savings classes, thereby raising the aggregate savings level. This "distributionally" mediated effect of growth on savings is different from that postulated by the life-cycle theories relying on the dependency ratio-for which there is no empirical confirmation for India. It provides a more plausible explanation of the virtuous circle whereby rapid growth, by moving low income-savings households into higher income-savings brackets, raises the aggregate savings rate, which in turn fuels rapid growth. The rise in labor supply during the demographic transition would of course still affect the "natural rate" of growth in the standard neoclassical growth framework, while the rise in the savings rate would lead to a higher rate of growth along the "traverse" as the economy moves from an initial low savings steady-state path to one with a higher savings and hence higher steady-state capital/labor ratio. This model was used in Lal and Natarajan (2001) to explain the aggregate savings rate for India during 1955-95 and performed well.

\section{The future}

Whether one believes in Williamson's demographic gift or the Lal-Natarajan view of the distributionally mediated determinants of savings, it is clear that, as long as India completes the reform process, including the rescinding of its century-old and deeply inefficient labor laws, there is no reason why, given a rising savings rate, India could not be growing at 8-10 percent per annum 
for the foreseeable future. Because population growth has begun to slow, this should provide a double hammer to deal with India's age-old scourge of structural poverty. Although there are signs that agricultural growth has slowed, largely because much of the potential irrigable area is already utilized and most of the cropped area suitable for high-yield varieties is already under this new technology, one sees both hope for more efficiency gains from the old "new" technology and the promise of a newer technology in the form of genetic modification (see Lal 2000). On the former point it is worth noting that efficiency gains are to be had from removing the continuing discrimination against agriculture in even the liberalized post-1991 trade regime (see Gulati 1998) as well as gains from exploiting India's comparative advantage, if the various barriers to world trade in agricultural goods are finally tackled by the World Trade Organization. On the latter, apart from offering various nutritive additions to traditional crops as in the "golden rice" that has been developed, genetic modification technology also promises to reduce the crop losses due to pests as with genetically modified cotton, while reducing the potential environmental damage from pesticides.

The most serious problems relate to the provision of infrastructure. Apart from the reforms needed in irrigation subsidies and power tariffs to improve the efficient use of existing infrastructure, there is also the need for massive investment in providing transport and power (see Ahluwalia 1998). The remedies for these planners' headaches exacerbated by population growth are well known.

There is a view current in India that with the explosive growth of services, particularly in information technology beginning in the 1990s, India can skip the usual stages of development, whereby agriculture is replaced by manufacturing industry as the leading sector and then by services, as in the post-industrial economies of the West. But given the size of the Indian population and the fact that, though literacy rates have risen, the educational levels (particularly in rural areas) of the majority are insufficient to allow them to participate in the human-capital-intensive services sector, India still needs to exploit its comparative advantage in labor-intensive manufacturing. This requires removing the remaining barriers to efficient industrialization, the most important of which remain the colonial industrial labor laws that have discouraged the use of labor in industry, and the set-asides for labor-intensive small-scale industry that prevent the exploiting of economies of scale.

\section{The environment}

The use of genetic modification technology in agriculture and the continuing need to expand labor-intensive manufacturing raise the specter that haunts environmentalists: the threats they see arising from India's burgeon- 
ing population. Economic historians (see Wrigley 1988) have established that the Industrial Revolution, which launched the era of modern intensive growth, was based on the transformation of an organic agrarian economy whose growth was ultimately bounded by a fixed factor, land, to a mineralenergy-using economy where the supply of energy from fossil fuels was for all practical purposes unbounded. This removed the constraints to a sustained rise in per capita income. Mass structural poverty need no longer be the inevitable fate of humankind. This process of transforming an organic into a mineral-energy-using economy, which India has fitfully engaged in, has already lifted millions out of poverty. For a full elimination of this ancient scourge India will have to consume even more energy from fossil fuels, which we are told will lead to global warming. I remain deeply skeptical (as do many others) about the underlying science and the dire effects predicted about global warming (see Lal 2006). But if India is forced to limit its greenhouse emissions from burning fossil fuels, it will indubitably condemn millions of poor Indians to perpetual poverty (see Lal 1995, 1997, 2006).

The attempt by environmental nongovernmental organizations like Greenpeace to push their agenda on a host of issues-including genetically modified foods, DDT, and trading in waste under the Basle treaty-also threatens the livelihood and welfare of millions of Indians (Lal 2000). India needs to beat off these threats to its poor as it has done to threats from the dirigiste planners of the Nehruvian era.

Nevertheless, there will be environmental problems associated with the rising per capita incomes of over a billion people. But as Panayotou (1994) rightly notes, most of these are best dealt with by setting up the right systems of incentives and disincentives. These include systems of property rights for hitherto common resources, proper pricing policies, and (where necessary) regulation to internalize externalities associated with the use of natural resources. The problems of deforestation, soil erosion, salinity, air pollution, and other forms of environmental degradation are due to the omissions and commissions of public policy "with price policies, taxes and subsidies encouraging environmentally destructive behavior" (Panayotou 1994: 177). These include corrupt logging contracts in the foothills of the Himalayas; irrigation, fertilizer, and power subsidies to the rural sector; and the failure to prescribe or enforce pollution standards for motor vehicles. In a dramatic example, when the Supreme Court, which is located in the capital, New Delhi, issued an order that by a certain date the government had to enforce various pollution standards (including the conversion of all diesel-powered public vehicles to the use of an alternative fuel), there was a remarkable improvement in the air quality in Delhi, which had been the second most polluted city in the world after Xian in China. There is thus no necessary conflict between the policies for efficient development and preserving the environment. 


\section{Social and political effects of population growth}

India, like most other great Eurasian agrarian civilizations, was until recently a labor-scarce and land-abundant economy. As Domar (1970) demonstrated in a sadly neglected essay, in such economies free labor, free land, and a nonworking population cannot coexist. Only two out of the three will be found together. For instance, if there are free peasants and abundant land then the marginal and average product of labor will be nearly the same. Hence no surplus will be available to support a nonworking population of soldiers and priests. All the great Eurasian agrarian civilizations were created by obtaining a surplus for use in the towns (civitas, being the emblem of civilization). This predatory purpose required that peasants in these land-abundant civilizations be tied down to the land: to provide the required labor for the intensive processes of plough agriculture and to allow the extraction of a surplus over subsistence to support the wielders of the pen and the sword in the towns.

The swordsmen were necessary, as these riverine Eurasian civilizations were sandwiched between two major areas of nomadic pastoralismthe grasslands of the great steppe regions to the north and the semi-desert of the Arabian peninsula to the south. The nomads of these regions had maintained many of the war-like organizations and violent habits of big game hunters characteristic of their hunter-gatherer ancestors. They constantly preyed on the more numerous but sedentary populations of the agrarian civilizations. In the subsequent collision between farmers and pastoralists, the inherent military advantages the latter enjoyed made the sword wielders among the farmers essential in preventing the pastoralists from conquering and exploiting them (see McNeill 1979: 23-25). There were thus important external exigencies for obtaining a surplus to support specialists in wielding the sword, commanded by some form of monarch. Moreover, this nomadic threat also induced the creation of empires in order to acquire more natural and easily defensible borders against the barbarians (see Lal 2004).

\section{Caste society}

The means used to tie down labor to land to extract the surplus- the caste system in India, various forms of serfdom in Europe and China, slavery in many civilizations-were determined more by ecology than ideology. But in many cases (like caste in India) an ideology or, as I prefer to call it, a set of cosmological beliefs (Lal 1998) became an essential element in maintaining the necessary social control.

In India, as I argued in The Hindu Equilibrium, Hindu civilization developed on the vast Indo-Gangetic plain. This geographical feature meant 
that, with the existing means of transportation and communication, the ancient Indian polity was marked by grave instability among numerous feuding monarchies, none of which could successfully establish hegemony over the vast plain for any sustained period. This political instability ruled out those forms of tying labor to land that required some means of political control. The ancient Hindus found in the caste system an apolitical decentralized system to tie labor down whose survival did not require any overall (and larger) political community, and ensured that any attempt to start new settlements outside its framework would be difficult if not impossible. The division of labor by caste and its enforcement by local social ostracism were central to the schema.

The endogamous specialization of the complementary services required as inputs in the functioning of a viable settlement, and the social sanctions against the imparting of these complementary skills to other castes, meant that it would be virtually impossible to organize caste-breaking coalitions (see Akerlof 1976; Lal 1988). Moreover, through the process of "preference falsification" (see Kuran 1995), the system could continue even in the presence of hidden dissent and led to a climate of opinion where even the oppressed internalized its hierarchical cosmology.

The resilience of the caste system is shown by the fact of its survival, even though since AD 1000 India has been ruled by foreigners whose egalitarian ideology would have been expected to undermine the hierarchical caste system. The system even had some success in converting its conquerors, who in the personal domain adopted many aspects of the caste system (see Lal 1988). Recently, a revisionist school of historians claimed that caste is a colonial construction reflecting the Orientalism denounced by Edward Said (see Chaturvedi 2000; Inden 1990). But, as I briefly discuss in the preface to Lal (2005), their case is unconvincing. Caste (particularly the pollution barrier it embodies) has played and continues to play a major role in Indian society and politics (see Srinivas 1996).

In keeping with my materialist explanation for the origins of the caste system, I would have expected its erosion with the ending of the scarcity of labor relative to land following the twentieth-century population expansion. This has not happened, for two reasons. First, as I noted in Unintended Consequences (Lal 1998), there is an important distinction between the material and the cosmological beliefs of civilizations. The former are beliefs relating to the material world and ways of making a living. They can change fairly rapidly with changes in the material environment. The latter are related to understanding the world around us and mankind's place in it, which determines how people view their lives in terms of purpose, meaning, and relationship to others. There is considerable cross-cultural evidence that cosmological beliefs are less malleable than material beliefs. Cosmological beliefs are determined more by the language group from which the culture 
arose than by the environment, and there is considerable hysterisis in these beliefs on how, in Plato's words, "one should live" (see Hallpike 1986). So these cosmological beliefs can persist even if the original ecological circumstances that gave rise to them change, or if the relevant group migrates to another location.

This means that, even though the material bases for the origins of the caste system have been eroded, the set of cosmological beliefs, which were part and parcel of the system of social control it embodied, continue to resonate in modern India. Although officially caste has been abolished, it remains the bedrock of political competition in the country. Its continuing hold on social attitudes is neatly captured by Susan Bayly's description of the 1997 inauguration of the first untouchable President of the country. She notes the amalgam of symbols from the Raj, the dharmic kingdom of Hindu maharajas, and the symbols of Kshatriya martial races at the inauguration of President K. R. Narayanan: " both the staging of the event and its media representations took for granted the existence of caste as a potent reality of Indian life, at least in the past as well as the immediate present, if not necessarily for the future" (Bayly 1999: 381). Given the resilience of cosmological beliefs, I would demur with her prognostications about the future.

The second reason for the resilience of caste is that the democratic system has inadvertently given it a fillip. This is best discussed in the context of the reasons for the survival of democracy in India when it has manifestly failed to secure any sort of resilient foothold in the rest of the developing world.

\section{Politics}

One of the critical consequences of the apolitical and decentralized caste system established in ancient India was that, by making war the trade of endogamously specialized professionals, the mass of the population was spared from being inducted into the deadly disputes of its changing rulers. At the same time, the ancient tradition of paying a customary share of village output as revenue to the current overlord meant that the victor had little incentive to disturb the daily business of his newly acquired subjects. The democratic practices gradually introduced by the British in the late nineteenth century fit these ancient habits like a glove. The ballot box has replaced the battlefield for the hurly-burly of continuing "aristocratic" conflict, while the populace accepts with ancient resignation that its rulers will, through various forms of "rent-seeking," take a certain share of output to feather their own nests. These age-old cosmological beliefs, in my view, explain why, unlike in so many other developing countries, democracy has thrived in such a vast, diverse, and poor country, and taken deep root-as was shown by Indira Gandhi's aborted attempt to stifle it during the Emergency. 
In the ensuing democratic political competition, caste affiliations remain of paramount importance, as witness the continuing attempt by successful political parties to constitute caste blocs. The higher ("twice born") castes have feared that relatively more rapid population growth among the lower castes and among the Muslim population would reduce their own political power. But this fear has remained unfounded. As Jeffery and Jeffery (1997) note, although there are differences in fertility rates between caste Hindus, Scheduled castes, and Muslims, with those for the first being the lowest, the differences can be explained in terms of income, education, child mortality, and age at marriage-the traditional socioeconomic variablesand not by caste or religion. Thus Cassen (1978: 57) rightly predicted that, ceteris paribus, the decline in Muslim fertility rates was about ten years behind that of Hindus, and that, even assuming the Muslim birth rates remain above Hindu rates, it is unlikely the Muslim proportion of the Indian population will rise to as much as 15 percent by 2021 .

Nor has the achievement of political power by the untouchables (Dalits)-heralded by the rise of their party, the Bahujan Samaj Party, and the temporary elevation of its leader to the Chief Ministership of the most populous state in the country, Uttar Pradesh-led to any radical transformation of Indian politics. As elsewhere, democratic politics in India is by its very nature a distributive zero-sum game (see Lal and Myint 1996). Given the politicized nature of the economy under the Nehruvian dispensation, political power also led to economic benefits for those successful in capturing the levers of the state. This inherent populism of democratic politics was enhanced by the Indian Constitution's stipulation that the backward castes and tribes should be given time-bound reservations for public posts and contracts. This provision has been used by populist politicians to create a vast extension of affirmative action for virtually the whole of the non"twice born" caste population, while ignoring the time-bound injunction. It has also accentuated the need to assert one's caste identity to obtain these politicized benefits, and has made both caste identity and assertion a central part of political competition in India. The liberalization of the economy in the 1990s and the resulting reduction in the attractiveness of public sector jobs have meant that the fierce opposition to this casteist affirmative action by the upper castes has also become muted. But if the rising demands for reservations in the private sector build up and are met, there will be a serious threat to India's future economic growth prospects.

Two questions have puzzled many observers of the Indian polity. First, how has a country with such linguistic, ethnic, cultural, and economic diversity managed to maintain its unity? Second, how could a subcontinental democratic polity with its equilibrium of "rent seeking interests" deliver economic liberalization? On the first, it is important to remember that like medieval Europe after the fall of Rome, the subcontinent has for millennia 
had a cultural unity provided by its Hindu cosmological beliefs despite long periods of political disunity. Moreover, India has always been a potential imperial polity. Although the imperial unity of the whole subcontinent has been ephemeral in Indian history because of the centrifugal tendencies dictated by geography and cycles in fiscal predation, the imperial ideal has animated every ruler of India. The British were the last of its rulers to turn this ideal into reality, and modern India is in many ways a continuation of the Raj (not least, as discussed below, because it has found it expedient to maintain the old imperial language of English as its lingua franca). The country has disposed of various militant separatist movements with an iron fist, while the democratic polity and the absorptive power of its cosmological beliefs have provided a means to eventually coopt dissidents into the polity.

On the second, Rob Jenkins (1999) in an important book has shown how, despite the breakdown of the Congress Party's dominance in the 1980s, the political players in the succeeding shifting coalitions at the center have skillfully used both a rearrangement of the previous spoils system and the various conflicts of interests among the numerous rent seekers to institute and continue economic reform. In this they have been helped by the improved economic productivity following liberalization, leading to larger rents, so that the predators got an unchanged share of a larger pie. This economic success has changed the perceptions of Western political scientists: having written a book called Democracy and Discontent: India's Growing Crisis of Governability in 1990, Kohli later edited a book entitled The Success of India's Democracy (2001).

\section{The English, caste mobility, modernization, and Westernization}

Given the fluidity of caste, as Srinivas (1966) had hypothesized, the process of caste mobility and thence class mobility has been the outcome of Sanskritization and Westernization, with the lower castes trying to assert a superior status by imitating the social habits of the upper castes. One of the surprising features of modern India is that, despite the desire and attempts by nationalist leaders to replace English as the lingua franca of the subcontinent, its role has been strengthened since Independence. This is because, since being reconstructed by the British Raj, the Indian state is a multiethnic empire, much like the former Austro-Hungarian empire. Just as in the latter, an imperial lingua franca has been adopted in preference to any language of the ethnic groups comprising the empire. Doing otherwise would immediately put one ethnic group at an advantage and would be fiercely resisted by members of other ethnic groups (see Lal 2004).

It was Macaulay's famous minute of 1833 that created a new Englishspeaking caste. In it he summed up the aim of English education in India 
as being the training of an English-educated middle class "who may be interpreters between us and the millions whom we govern; a class of persons, Indian in blood and colour, but English in taste, in opinions, in morals, and in intellect" (Macaulay 1898, vol. xi: 385-386). In this, the Raj was successful.

Because it is the language group that determines people's cosmological beliefs (Hallpike 1986), the cosmological beliefs of the full-fledged members of the caste for whom English had become their first language were more likely to conform to the beliefs of their linguistic cousins in the West than those of their vernacular countrymen. They were Westernized in a way that those for whom English is a second or third language were not.

All the early leaders of the nationalist movement were thus Macaulay's children. Among them two branches can be distinguished: the Nehruvians and the Gandhians. Both believed that modernization and Westernization were linked. But whereas the Nehruvians, who, despite lip service to marrying Indian with Western culture, accepted the implication and sought to implement a particular secular set of Western cosmological beliefs, the Gandhians (whose cultural successors include the various Hindu nationalist groups) have sought to resist modernization for fear it would lead to Westernization.

But, as I argued in Unintended Consequences, this was a false choice. As Japan was the first to show, it is possible to modernize without Westernizing, a process in which the role of English would be instrumental. For the myriad district- and lower-level service functionaries whose first language remained their vernacular, the English they spoke as a second or third language already fulfilled this role. They were not infected by Western cosmologies like the English-speaking caste. Even though they were not Westernized, they could have been modernizers. It was fateful that during the nationalist struggle they were politically mobilized by Mahatma Gandhi, that other child of Macaulay. For unlike the modernizers, Gandhi was above all concerned with maintaining a refurbished Hindu equilibrium. But by equating modernization with Westernization he created a backlash not only against the cosmological views of the West, but also against its material beliefs. Many of the views of the Hindu nationalists and the various "poujadist" and "kulak" political parties reflected this confusion (Lal 1999)

The field was then left clear for the modernizers-cum-Westernizers, symbolized most powerfully by the iconic figure of Jawaharlal Nehru. The English-speaking caste was during this period at the apex of the social pyramid. But with the economic failure of the Nehruvian model, an unintended consequence was that its progeny could not find satisfying or remunerative employment at home, and large numbers of them emigrated to the West.

With the abandonment of the Nehruvian model, the "intermediate" castes for whom English was a second or third language came to the fore. 
But to the surprise of many, they did not, as had been expected, eschew modernization like their Gandhian predecessors. This change was completed when the Hindu nationalist party, the Bharatiya Janata Party, once in power did not turn its back on the economic reforms and the globalization that are so essential for India's modernization. These intermediate castes have increasingly come to accept that it is possible to modernize without Westernizing, and that in this task English serves a useful instrumental purpose. This has meant that, as soon as any part of rural India becomes prosperous, one of the first investments made by its residents is in private English-language schools. Furthermore, many members of these intermediate castes have progeny who along with English as their second language have also acquired the new information technology skills, which besides bringing them prosperity at home also provide a ticket to employment abroad.

This has resulted in a strange paradox, namely that many of the children of politicians and the administrative elite of both branches of Macaulay's children are now in the West. The political consequence has been that one of the Bharatiya Janata Party's early election pledges, to allow dual citizenship to the by-now-substantial Indian diaspora, is about to be redeemed-but with an interesting twist. It is only to be granted to persons of Indian origin who live in countries that recognize dual citizenship, namely, Britain and United States. By imposing this restriction they prevent the entry to India of the large number of Bangladeshis and Pakistanis who could otherwise claim Indian citizenship, while allowing the children of the older and newer political and administrative elites to at least metaphorically return to India.

To provide some rough orders of magnitude, Tata Services' Statistical Outline of India 1995-6 (Table 234) estimates that, in June 1987 about 12.7 million persons of Indian origin were residing abroad. Of these about 6 percent were in Canada and the United States, and another 6 percent in Britain. ${ }^{12}$ They are mainly the children of the two wings of Macaulay's children (of either kind) who will be eligible for dual citizenship. What role they will play in future Indian politics, given their relative wealth, is an intriguing question. But the diaspora does suggest that the process of caste mobility through the acquisition of English as a first or second language is likely to cut through the familiar caste patterns, even though in the personal domain-as the advertisements for arranged marriages for non-resident Indians in Indian newspapers testify-the desire to maintain caste endogamy endures.

One final aspect of the role of caste and politics is worth mentioning. The process of modernization is by its very nature disenchanting as people have to move to unfamiliar locations and undertake new tasks. The resulting turmoil in many modernizing societies has provided fertile ground for radical movements, which feed on the ensuing anomie. Apart from a few 
outbreaks of radical violence in the rural countryside, this has not happened in India, much to the chagrin of those of a Marxist bent of mind. I would suggest that it is the continuing resonance of the caste system's cosmological beliefs which provides the answer. Louis Dumont (1970) maintained that the great divide in human societies was between those who believed in "Homo Hierarchicus" and those in "Homo Aequalis," which in turn was based on the division between polytheistic and monotheistic religions, with the latter being egalitarian. Indian caste society is a prime example of a society of "Homo Hierarchicus," and as such egalitarianism has not had much resonance-except in rhetorical political terms. Therefore the resentments that would have been bred in a country with more egalitarian cosmological beliefs have not materialized. Equally important is the role of caste affiliations in providing both a social safety net and a framework to overcome the anomie that modernization would otherwise breed.

\section{The family, social security, health, and education}

India has maintained its traditional extended family system. Despite the fears of cultural nationalists, the rising new middle classes still adhere to traditional family values (Lal 1998, 2006). These were common to all ancient agrarian civilizations. In Unintended Consequences I argued, following Goody (1983), that the Papal revolution of Gregory the Great in the sixth century overturned the traditional patterns of legal and customary practices in the domestic domain in the West. The traditional system, concerned with providing a male heir to inherit family property, allowed marriage to close kin, marriages to close affines or widows of close kin, the transfer of children by adoption, and concubinage. Gregory banned all these practices, even though there was no basis for his injunctions in Scripture, Roman law, or existing customs in the areas that were Christianized. The purpose of the ban was to prevent families from having male heirs so that they could instead leave their property to the Church.

As part of this family revolution, the Church also promoted individualism through proclaiming the independence of the young: in choosing marriage partners, in setting up their households, and in entering into contractual rather than affective relationships with the elderly. The Church promoted love marriages rather than the arranged marriages that had existed in all Eurasian civilizations. A major consequence of Gregory's family revolution was that the social safety nets provided by the family in most Eurasian societies had from an early date to be provided by the state in the West.

There has been a fear that modernization will also breed Westernization and erode these traditional family-based social safety nets in India. But this fear seems to be misplaced. Thus a recent survey of the attitudes of 18 35 -year-old urban Indians in the vanguard of globalization found that 70 
percent would rather live in a joint than a nuclear family; 71 percent would not consider an old-age home for an elderly person in their family; 75 percent would not want a live-in relationship with someone before marriage; and 88 percent find kissing in public unacceptable. ${ }^{13}$ This implies that the problems of pensions and healthcare for the aged, which are increasingly facing the West and China, are unlikely to be a problem in India, given its shame-based culture and the continuing hold of its traditional cosmological beliefs, which require the care of the aged within the extended family.

Furthermore, with the dismal failure of the Indian state to provide the merit goods of education and health to its population, most are privately provided and financed by the extended family. The World Bank (2000) found "private delivery of health and education is expanding rapidly, to the public in general and even to the poor" (p. 21). The PROBE team (1999) found that one-fifth of the children enrolled in private schools came from casual labor and one-half from scheduled castes or backward caste groups. In Uttar Pradesh 36 percent of children attending school are enrolled in private schools. The best course for the public education system is for it to be privatized, with public expenditure being used to provide vouchers for the poor to send their children to school. Similarly for health, a National Sample Survey (GOI 1999) finds that the failings of the public health system are leading to rising demand for private health services. Of India's overall health expenditure, representing 6 percent of gross domestic product, nearly 80 percent is spent on private health care. As with education, current public health expenditure should be used to provide vouchers for the poor.

It seems, therefore, that India will be able to avoid many of the pitfalls of Western welfare states. It can continue to rely on traditional family-based social safety nets. And it may not have the need for the state welfare systems resulting from Gregory the Great's family revolution in the West, with all the social and economic dysfunction that it has entailed.

\section{The future of international relations}

We can conclude by speculating on the likely effects of India's burgeoning population on its role in the world order. Because the momentum of its population growth is greater than China's, India will likely be the most populous country in the world by the end of the twenty-first century. Economically, in a globalized world, size does not matter, as witness the notable examples of Hong Kong and Singapore. But in global politics, population size, if married to economic and technological might, can be decisive (see Lal 2004). Given the large disparities in per capita income between India and the West, even if India grew at 8 to 10 percent per annum it would take until the end of the century for India to catch up economically with the West. But, given the relative size of India's population, its total gross 
domestic product would surpass that of the United States by about 2050. Part of that increase in output will undoubtedly be put into military weapons and into attempts to close the technological gap, now so overwhelming, between India and the West. Also, there is the sheer number of warriors that India could put in the field. So what are likely to be the international aims of this economically growing large population?

In the eighteenth and nineteenth centuries India and China felt the brunt of European economic and military superiority through direct and indirect imperialism, which stood in sharp contrast to the economic and technological stagnation of what had hitherto been the leading and most prosperous imperial systems in the world. Their current conception of international relations is deeply influenced by the perceived humiliations of this European onslaught and marked by a fierce determination that history will not repeat itself.

With the reemergence of the Asian giants as growing economic powers, India and China are regaining their relative importance in the world. After their long relative economic decline (see Figure 1, in Lal 2004), they are now on the way to becoming, with the United States, the dominant economic powers in the world for the twenty-first century. Like the United States and Germany in the nineteenth century when the British provided a global Pax, India and China may at first be silent freeriders on the current US Pax, and then challenge it as their economic and military strength (given by both population and per capita income) matches that of the current global hegemon. Many in the United States (see Mearsheimer 2001) harbor such fears particularly about China, which is also a fear shared by India. I am more sanguine. For I note that in their long history both imperial states have largely been "status quo" powers whose expansion has been to defensible frontiers.

Historically, the main threat to Indian security has always been from the northwest, even though the Chinese incursions in the 1960s showed that the Himalayas were no longer an impregnable shield to the north. For the foreseeable future the twin threats posed on these frontiers are likely to determine India's policies in international relations, as they have for the last half century.

The threat from the northwest is more immediate and more insidious. A hostile nuclear state, Pakistan, within the Himalayan shield seeking to exploit the tensions within a multi-ethnic empire poses a difficult dilemma. Being a potentially failed state with a fragile economy, and with its only sense of national identity provided by being anti-Indian, it is a difficult neighbor to live with. But, if the recent attempt by General Musharaff to turn Pakistan into a more normal and economically viable state is successful, the vision which I heard Jawaharlal Nehru enunciate in one of his last speeches as foreign minister of the desirability of a subcontinental confederation of 
states might be the answer. This vision has surprisingly been reexpressed by the former hard-line Hindu nationalist BJP interior minister L. K. Advani. But one should not hold one's breath, expecting this outcome.

In the longer term, competition for Great Power influence in Asia with the other colossus, China, seems inevitable. This long-term economic and military competition between the world's most populous nations will no doubt be of great importance for international relations by the end of the century. But with both potential Great Powers increasingly integrated into the world economy and dependent for their growing economies on imported natural resources, they will have a clear incentive to cooperate in keeping the lanes of commerce open and free from predators. Because most natural resources are now internationally traded commodities on NYMEX, owning these resources is of little importance, as the opportunity cost of their use is given by their changing world prices. More important is to ensure the security of trading these resources from the depredations of the equivalent of pirates of yore. The three imperial powers-the United States, China, and India-are all actual or potential natural resource importers. They would have a common interest in maintaining open sea and air lanes. The current race for owning global natural resources by the Asian giants is questionable.

Finally, another prospect is reminiscent of the British Raj. One of the reasons India was the jewel in its crown was the large Indian army, paid for by Indian taxes and deployed by the Raj to maintain its Pax from Suez to the Far East. Today with the Islamist threat to the world's oil supplies and domestic order, and the perceived threat from China, US and Indian interests are converging. So it is not surprising that, since the United States launched its war on terrorism, the Indians are cooperating with the United States in guarding the sea lanes from the Arabian Sea to the straits of Malacca. The recent strategic partnership forged by President Bush and Prime Minister Manmohan Singh, which envisages technical cooperation in nuclear and missile technology, presages a growing partnership between these two democratic powers. In my view the aim of such a partnership should not be to contain China, whose rise is inevitable and, as it has embraced the liberal international economic order, likely to be peaceful, but to move toward an informal tripartite concert of imperial powers to maintain the global Pax. The United States seems to be using China in its prickly dealings with the North Koreans, which might presage such an alliance.

With its domestic and near-neighborly problem with Islamicists, it is easy to imagine a time when, as during the British Raj, India would join the United States in some form of indirect imperialism to maintain order in the Middle East. In the nineteenth century, during its rise to world economic superiority, the United States depended on the British Pax to protect it from the machinations of the European powers, while it took responsibility for maintaining order in its own hemisphere. Now it is possible 
to envisage a global concordat where, within an overall US Pax, the responsibility for maintaining a Pax in East Asia would be taken over by China, with Japan and the United States maintaining a shield to ensure China does not overreach itself; while India would assume the responsibility (possibly with Turkey, the older imperial power) for maintaining the Pax in West Asia. But this would have to await a rapprochement with Pakistan and possibly the burning out of the Islamicist fervor that has so destabilized the Middle East.

Unlike the previous imperial powers in the region, the Turks and the British, India has always been a multi-ethnic empire that has not sought to impose a universal ideology on its peoples. Both the United States and China are by contrast homogenizing empires seeking to impose a common set of values on their constituents (Lal 2004). This could backfire and lead to political miscalculations in the imperial task (as demonstrated by the aftermath of the Iraq war). A regional Pax maintained by a multi-ethnic India is likely to be more successful in dealing with the political fissures of West Asia. Even though with its current technological hubris the United States may not wish to forge an alliance, and given their prickly nationalism the Indians are unlikely to mobilize armed manpower to maintain the Pax of the current imperial power, future developments may lead to something short of a formal alliance between the current hegemon and a rising great power.

Reading the tea leaves for the rest of century is a near impossible task. Two things, however, are certain. India and China will be the most populous countries in the world. If their current economic progress continues (and there is little reason to doubt it will), they will also be the largest economies after the United States by mid-century. Despite fears expressed by many "declinists" (see Ferguson 2002), I do not expect the United States to lose its technological and economic superiority before the end of the century (see Lal 2004). But the United States will be under serious threat from the Asian giants. Given its dismal pre-university educational system, the United States has increasingly relied for its technological superiority on its open door policy of importing the best brains from around the world. In this new world economic order, human capital (including skills in governance) will be of prime importance in determining the relative wealth of nations. As the two Asian giants create the conditions for the efficient deployment of their human capital, they will eventually have an edge over other countries because of their large populations. Julian Simon had argued in The Ultimate Resource (1981) that, as natural intelligence can be expected to be normally distributed in a population, the number of geniuses in the upper tail would be higher, ceteris paribus, in a larger population. This might soon come to pass, with these Asian geniuses choosing to work in their own countries rather than as at present in the United States. Thus, if not the current, 
then the twenty-second century is likely to belong to the Asian giants, whose large populations instead of being their bane (as had long been feared) will be the source of their greatness.

\section{Notes}

1 A revised, updated, and abridged version of The Hindu Equilibrium was issued in 2005 (Lal 2005).

2 It might be worth noting that, at Nancy Birdsall's instigation, Martin Wolf and I were responsible for part I of the 1984 World Development Report, which is rightly seen as a marker of the shift in World Bank thinking on population issues. There we discussed, for the first time, the implications of the aging of the population in the West for its economies and those of developing countries in an interdependent global economy (see Lal and Wolf 1986).

3 Eberstadt (2005) has usefully distinguished between the neo-Malthusianism of the past, represented for instance by the famous study by Coale and Hoover (1958), which asserted that wealth and productivity would be sacrificed by countries that threw resources away on extra babies instead of husbanding resources for investment and growth, and the current "environmental Malthusianism," which asserts that "rising demands upon the planetary eco-system will result in catastrophic overshoot and collapse of the natural global systems that sustain us all" (p. 479). See Lal (2006) for a discussion of why I find this assertion unpersuasive.

4 Pecuniary externalities are indirect effects mediated through the price mechanism, when, say, the increase in the supply of a good leads to a fall in its price, which harms other producers of the good but benefits consumers. These externalities are Pareto-irrelevant in the language of welfare economics. By contrast, technological externalities like smoke from a factory are not mediated through the price mechanism and are Pareto-relevant, leading to "market failure," which could require corrective public action. See Buchanan and Stubbelbine (1962).

5 I eschew any discussion of the various statistical problems involved in Indian demo- graphic data. Visaria (1987) provides a succinct discussion of the matter.

6 The slowing down of the population growth rate in the 1901-21 period was due to the frequent epidemics of plague and cholera and the influenza epidemic of 1918-19, which raised the death rate in the 1911-21 census period to nearly the level of the birth rate. The growth rate of population was also lowered in the 1941-51 period by the Bengal famine of 1943, which killed an estimated 1.5-3 million people (Sen 1982), and the slaughter associated with the 1947 partition of Imperial India and the dislocation associated with "the total post-partition migration of nearly 15 million persons to and from India" (Visaria (1987): 136). The decline in the mortality rate in the 1950s was due to the control of malaria through low-cost spraying with DDT and the control of infectious diseases, particularly tuberculosis, through the introduction of antibiotics. But the decline in the death rate has slowed since 1961-71.

7 The spike in the infant mortality rate in 1911-21 was due to the epidemics discussed above. Since then it has been steadily declining, with the birth rate-as theory predicts-following suit, except for the substantial fall and then rise in the latter during the 1940s-50s. Visaria (1987) confirms that this is not a statistical artifact. But subsequently the birth rate has followed the infant mortality rate downward, although with some sluggishness during the 1960s, an acceleration in the 1970s, and from the annual data for birth rates an apparent stability between 1979 and 1984, since when there has been a rapid decline.

8 The fall seen in 2001 is probably due to the improved coverage of females in the 2001 as compared with the 1991 census, and the same seems to be the case with the reported declines in 1951 and 1981 (see Dyson 2001). 
9 There is also an implicit assumption in steady state growth theory that colors much thought on the population question. This was explicitly and succinctly outlined by Sir J. R. Hicks (1977). The assumption is that "a steady-state expansion, in which capital per head was constant and there was no technical progress, would show no gain in productivity. The expanded population would be absorbed, but that would be all. In such a steady state there would be no rise in real incomes and no rise in real wages. But in this steady-state theory is there not an important element which is being neglected? Is it not the case that expansion as such, even population-based expansion, is favourable to productivity?" (p. 23). The Boserup model on the role of population growth in inducing technical change in agriculture, briefly discussed below, fits the Indian "facts" better than Malthusian explanations.

Moreover, even without any induced technical change, as the population expansion is absorbed in an open economy with constant terms of trade at an unchanged real wage, following the Rybczynski theorem, this does not imply a lower social welfare because many ethical systems (such as the Utilitarian and Catholic) would include the number of heads along with consumption per head as positive arguments in a society's social welfare function.

10 Pryor and Maurer (1982) formalize this model and also provide a more general model that includes both the Malthusian and Boserupian positions as special cases. Also see Lal (1998: Appendix) for a diagrammatic explication of the model.

11 Both China's and India's recent outward-looking policy stances risk the danger that rising protectionist pressures in the North might thwart their rapid expansion. Given the history of the inter-war years this possibility cannot be completely discounted; however, it is encouraging that the substantial changes in the international division of labor that have already taken place have been accommodated with little backlash. Perhaps the mutually beneficial gains from trade are at last being realized as such, except for the anti-globalization fringe. I argue in Lal (2006) that the fear of a breakdown of the current liberal international economic order cannot be altogether discounted. But that does not mean that India and China need to change their current course to forestall a small possible threat to openness in the global economy in the future.

12 One of the major differences between the period of globalization in the nineteenth century and the current one is that whereas there was completely free movement of labor in the earlier period, immigration controls have become ubiquitous since then. This is because of the rise of welfare states in Bismarck's Germany, Lloyd George's Britain, and Franklin Roosevelt's United States. A welfare state creates property rights in citizenship because it allows any citizen access to the purses of its fellows. This makes the granting of citizenship to new entrants with incipient claims on existing citizens a major political issue. This has meant that whereas in the nineteenth century there was large emigration of the burgeoning peasants from India and China to the West and its tropical colonies in the Caribbean, Africa, and Latin America, in the twentieth century the immigrants allowed into the West have been largely the skilled. The peasantry from the subcontinent who settled in Britain entered just after World War II and before immigration controls were imposed in the 1960s. Most of the first-generation Indian diaspora today in the West thus consists of its relatively highly skilled rather than its peasantry. The latter have, however, found lucrative temporary jobs in the oil-rich countries of the Middle East. Today, with the aging of the population in Europe and the United States, immigration is being encouraged in part to deal with the problem of future pensions, but it is highly selective, being biased toward the skilled. This has meant that, whereas in the nineteenth-century period of globalization, migration of the unskilled was as important for the international convergence of factor prices as foreign trade (see $\mathrm{O}^{\prime}$ Rourke and Williamson 1999), today trade is the major though less potent force leading to factor price convergence.

13 "Sex, society and the family," India Today International, 31 January 2005, pp. 3437. These results are based on a poll conducted by AC Nielsen-Org-Marg of a crosssection of the population aged 18-35 years across ten major representative urban centers. 


\section{References}

Ahluwalia, I. J. and I. M. D. Little (eds.). 1998. India's Economic Reforms and Development. Delhi: Oxford University Press.

Ahluwalia, M. S. 1998, "Infrastructure development in India's reforms," in I. J. Ahluwalia and I. M. D.Little (eds.), pp. 87-121.

Akerlof, G. 1976. "The economics of caste and of the rat race and other woeful tales," Quarterly Journal of Economics 90(4): 599-617.

Bardhan, P. K. 1979. "Labour supply functions in a poor agrarian economy," American Economic Review 69(1): 73-83.

- 1984. "Determinants of supply and demand for labour in a poor agrarian economy," in Binswanger and Rosenzweig (eds.).

Barro, R. 2005. "The case of Asia's 'missing women,'” Business Week, 28 February.

Bayly, S. 1999. Caste, Society and Politics in India. Cambridge: Cambridge University Press.

Becker, G. 1981, 1991. A Treatise on the Family. Cambridge, MA: Harvard University Press.

Bhalla, S. 1979. "Measurement errors and the permanent income hypothesis: evidence from rural India," American Economic Review 69: 295-307

. 1980. "The measurement of permanent income and its application to savings behavior," Journal of Political Economy 88: 722-743.

Bhat, P. N. Mari. 1998. "Contours of fertility decline in India: An analysis of district-level trends from two recent censuses," in Martine et al. (eds.), pp. 97-168.

Binswanger, H. and M. R. Rosenzweig (eds.) 1984. Contractual Arrangements, Employment and Wages in Rural Labour Markets in Asia. New Haven: Yale University Press.

Birdsall, N., A. C. Kelley, and S. W. Sinding (eds.) 2001. Population Matters. Oxford: Oxford University Press.

Blaug, M., P. R. G. Layard, and M. Woodhall 1969. The Causes of Graduate Unemployment in India. London: Allen Lane.

Boserup, E. 1965. The Conditions of Agricultural Growth. London: Allen and Unwin.

Buchanan, J. M. and C. Stubbelbine. 1962. "Externality," Economica 29: 371-384

Cassen, R. M. 1978. India: Population, Economy, Society. London: Macmillan.

Chaturvedi, V. (ed.) 2000. Mapping Subaltern Studies and the Post Colonial. London: Verso.

Coale, A. J. and E. M. Hoover. 1958. Population Growth and Economic Development in Low Income Countries: A Case Study of India's Prospects. Princeton: Princeton University Press.

Dandekar, V. M. 1988. "Indian economy since independence," Economic and Political Weekly 23(1-2):

Das Gupta, M. 1998. "Fertility decline in Punjab, India: Parallels with historical Europe," in Martine et al. (eds.), pp. 65-96.

- 2005. "Explaining Asia's 'missing women': A new look at the data," Population and Development Review 31(3): 529-535.

Das Gupta, M. and M. Bhat. 1999. "Intensified gender bias in India: A consequence of fertility decline," in M. Krishnaraj, R. M. Sudarshan and A. Shariff (eds.), Gender, Population and Development. Delhi: Oxford University Press, pp. 73-93.

Deaton, A. 1990. "Savings in developing countries: Theory and review," World Bank Annual Conference on Development Economics, pp. 61-96.

Domar, E. 1970. "The causes of slavery or serfdom: A hypothesis," Journal of Economic History 30(March): 18-32.

Dumont, L. 1970. Homo Hierarchicus. London: Weidenfeld and Nicholson.

Dyson, T. 2001. "The preliminary demography of the 2001 census of India," Population and Development Review 27(2): 341-356.

Eberstadt, N. 2005. “P. T. Bauer on the population question," Cato Journal 25(3): 471-481.

Ehrlich, P. 1968. The Population Bomb. Baltimore: Ballantine.

Evenson, R. and H. Binswanger. 1984. “Estimating labour demand functions for Indian agriculture," in Binswanger and Rosenzweig (eds.).

Fei, J. C. and G. Ranis. 1964. The Development of a Labour Surplus Economy. Homewood, IL: R.D. Irwin. 
Ferguson, N. 2002. Colossus. London: Allen Lane.

Goody, J. 1983. The Development of the Family and Marriage in Europe. Cambridge: Cambridge University Press.

. 1990. The Oriental, the Ancient and the Primitive. Cambridge: Cambridge University Press.

— 1996. "Comparing family systems in Europe and Asia," Population and Development Review 22(1): 1-20.

Government of India (GOI). 1999. "Survey on Health Care," 52nd Round (July 1995- June 1996) Schedule 25, NSS Organization, Department of Statistics.

Gulati, A. 1998. “Indian agriculture in an open economy: Will it prosper?," in I. J. Ahluwalia and I. M. D.Little (eds.), pp. 122-146.

Hallpike, C. R. 1986. The Principles of Social Evolution. Oxford: Clarendon Press.

Harrod, R. F. 1948. Towards a Dynamic Economics. London: Macmillan.

Hicks, J. R. 1977. Economic Perspectives. Oxford: Oxford University Press.

Inden, R. B. 1990. Imagining India. Bloomington: Indiana University Press.

Ishikawa, S. 1967. Economic Development in Asian Perspective. Tokyo: Kinokuniya.

Jeffery, R. and P. Jeffery. 1997. Population, Gender and Politics. Cambridge: Cambridge University Press,

Jenkins, R. 1999. Democratic Politics and Economic Reform in India. Cambridge: Cambridge University Press.

Kaldor, N. 1955-56. "Alternative theories of distribution," Review of Economic Studies 23: 83100 .

Kelley, A. C. 2001. "The population debate in historical perspective: Revisionism revised," in Birdsall et al. (eds.), pp. 24-54.

Kohli, A. 1990. Democracy and Discontent; India's Growing Crisis of Governability. Cambridge: Cambridge University Press.

(ed.). 2001 . The Success of India's Democracy. Cambridge: Cambridge University Press.

Kumar, B. Gopalakrishna. 1993. “Quality of life and nutritional status: A reconsideration of some puzzles from Kerala," in P. Bardhan, M. Datta-Chaudhuri, and T. N. Krishnan (eds.), Development and Change. Oxford: Oxford University Press.

Kuper, A. 1994. The Chosen Primate. Cambridge, MA: Harvard University Press.

Kuran, T. 1995. Private Truths, Public Lies. Cambridge, MA: Harvard University Press.

Lal, D. 1983/2000. The Poverty of "Development Economics." London: Institute of Economic Affairs; Cambridge, MA: MIT Press, 2nd US edition.

. 1988/1989. The Hindu Equilibrium, 2 vols. Oxford: Clarendon Press.

- 1988a. "The determinants of urban unemployment in India," Indian Economic Review XXIII(1): 61-81.

. 1995. "Ecofundamentalism," International Affairs 71 (July): 22-49.

- 1997. "Ecological imperialism: The prospective costs of Kyoto for the Third World," in J. H. Adler (ed.), The Costs of Kyoto. Washington, DC: Competitive Enterprise Institute, pp. 83-90.

1998. Unintended Consequences. Cambridge, MA: MIT Press.

. 1999. Culture, Democracy and Development, Golden Jubilee Seminar Series. New Delhi: NCAER.

— 2000. "The new cultural imperialism: The greens and economic development," inaugural Julian Simon memorial lecture, Occasional Paper 5, Liberty Institute, New Delhi.

- 2004. In Praise of Empires. New York: Palgrave-Macmillan.

. 2005. The Hindu Equilibrium: India c.1500 BC-2000 AD, revised and abridged. Oxford: Oxford University Press.

—. 2006. Reviving the Invisible Hand: The Case for Classical Liberalism in the Twenty-First Century. Princeton: Princeton University Press.

Lal, D., R. Mohan, and I. Natarajan. 2001. "Economic reforms and poverty alleviation: A tale of two surveys," Economic and Political Weekly XXXVI(12): 1017-1028. 
Lal, D. and H. Myint. 1996. The Political Economy of Poverty, Equity and Growth. Oxford: Clarendon Press.

Lal, D. and I. Natarajan. 2001. "The virtuous circle: Savings, Distribution and growth interactions in India," in D. Lal and R. H. Snape (eds.), Trade, Development and Political Economy. Basingstoke, Hampshire: Palgrave, pp. 213-228.

Lal, D. and M. Wolf (eds.). 1986. Stagflation, Savings and the State. New York: Oxford University Press.

Lee, R. D. and T. Miller. 1990. "Population growth, externalities to childbearing, and fertility policy in developing countries," Proceedings of the World Bank Annual Conference on Development Economics 1990, pp. 275-304.

Lewis, W. A. 1954. "Economic development with unlimited supplies of labour," Manchester School, vol. 22, pp. 139-191.

Lipson, C. 1985. Standing Guard. Berkeley: University of California Press.

Macaulay, T. B. 1898. The Complete Works of Lord Macaulay, 12 vols. London.

Mamdani, M. 1972. The Myth of Population Control. New York: Monthly Review Press.

Martine, G., M. Das Gupta, L. C.Chen (eds.). 1998. Reproductive Change in India and Brazil. Delhi: Oxford University Press.

Mayer, P. 1999. "India's falling sex ratios," Population and Development Review 25(2): 323343.

McNeill, W. H. 1979. A History of the World, 3rd edition. New York: Oxford University Press.

Mearsheimer, J. J. 2001. The Tragedy of the Great Powers. New York: W. W. Norton.

Mehra, S. 1966. "Surplus labour in Indian Agriculture," Indian Economic Review 1.

Modigliani, F. 1970. "The life cycle hypothesis of savings and inter-country differences in the saving ratio," in W. A. Eltis, M. Scott and J. N. Wolfe (eds.), Induction, Trade and Growth. Oxford: Oxford University Press, pp. 197-225.

O'Rourke, K. H. and J. G. Williamson. 1999. Globalization and History. Cambridge, MA: MIT Press.

Oster, E. 2005. "Hepatitis B and the case of the 'missing women,'” Harvard University Center for International Development, Working Paper 7, Cambridge, MA.

Panayotou, T. 1994. "Population, environment and development nexus," in R. Cassen (ed.), Population and Development: Old Debates, New Conclusions. New Brunswick: Transaction Publishers, pp. 149-180.

PROBE Team. 1999. Public Report on Basic Education in India. New Delhi: Oxford University Press.

Pryor, F. L. and S. B. Maurer 1982. "On induced economic change in pre-capitalist societies," Journal of Development Economics 10(3): 325-353.

Rosenzweig, M. 1978. "Rural wages, labor supply, and land reform: A theoretical and empirical analysis," American Economic Review 68(5): 847-861.

. 1980. "Determinants of wage rates and labor supply behavior in the rural sector of a developing country," in H. Binswanger and M. R. Rosenzweig (eds.).

. 1988. "Risk, implicit contracts and the family in rural areas of low income countries," Economic Journal 98(Dec.): 1148-1170.

Sen, A. K. 1966. "Peasants and dualism with and without surplus labour," Journal of Political Economy 74: 425-450.

1982. Poverty and Famines. Oxford: Clarendon Press.

1990. "More than 100 million women are missing," New York Review of Books, 20 December: 61-66.

Simon, J. 1981. The Ultimate Resource. Princeton: Princeton University Press.

Sivasubramonian, S. 2000. The National Income of India in the Twentieth Century. Delhi: Oxford University Press.

Srinivas, M. N. 1966. Social Change in Modern India. Berkeley: University of California Press. . 1996. Village, Caste, Gender and Method. New Delhi: Oxford University Press.

Summers, L. H. and C. Carroll. 1989. "The growth-savings nexus," paper presented at the NBER Conference on Savings, Maui, Hawaii, January. 
Tendulkar, S. D. 1998. "Indian economic policy reforms and poverty: An assessment," in I. J. Ahluwalia and I. M. D. Little (eds.), India's Economic Reforms and Development: Essays for Manmohan Singh. New Delhi: Oxford University Press, pp. 280-309.

United Nations. 2002. World Population Prospects: The 2002 Revision. New York: United Nations Population Division.

Visaria, P. 1987. “The demographic dimensions of Indian economic development since 1947," in P. R. Brahmananda and V. R. Panchmukhi (eds.), The Development Process of the Indian Economy. Bombay: Himalaya Publishing House.

Visaria, P. and B. S. Minhas. 1991. “Evolving an employment policy for the 1990's: What do the data tell us?," Economic and Political Weekly XXVI(15). Reprinted in U. Kapila (ed.), 1993, Indian Economy since Independence, Vol. 4. Delhi: Academic Foundation, pp. 136-174.

Williamson, J. G. 2001. “Demographic change, economic growth and inequality," in Birdsall et al. (eds.), pp. 106-136.

World Bank. 2000. India: Reducing Poverty, Accelerating Development. New Delhi: Oxford University Press.

Wrigley, E. A. 1988. Continuity, Chance and Change, Cambridge. Cambridge: Cambridge University Press, .

Wyon, J. B. and J. E. Gordon. 1971. The Khanna Study. Cambridge, MA: Harvard University Press.

DEEPAK LAL is James S. Coleman Professor of International Development Studies, University of California, Los Angeles. 